University of Nebraska - Lincoln

DigitalCommons@University of Nebraska - Lincoln

Educational Psychology Papers and

Publications

Educational Psychology, Department of

June 2005

\title{
Commentary on Evidence-based Parent and Family Interventions: Will What We Know Now Influence What We Do in the Future?
}

Susan M. Sheridan

University of Nebraska-Lincoln, ssheridan2@unl.edu

Follow this and additional works at: https://digitalcommons.unl.edu/edpsychpapers

Part of the Educational Psychology Commons

Sheridan, Susan M., "Commentary on Evidence-based Parent and Family Interventions: Will What We Know Now Influence What We Do in the Future?" (2005). Educational Psychology Papers and Publications. 14.

https://digitalcommons.unl.edu/edpsychpapers/14

This Article is brought to you for free and open access by the Educational Psychology, Department of at DigitalCommons@University of Nebraska - Lincoln. It has been accepted for inclusion in Educational Psychology Papers and Publications by an authorized administrator of DigitalCommons@University of Nebraska - Lincoln. 


\title{
Commentary on Evidence-based Parent and Family Interventions: Will What We Know Now Influence What We Do in the Future?
}

\author{
Susan M. Sheridan \\ University of Nebraska-Lincoln
}

As has been demonstrated in this exceptional review of the empirical literature, much has been written about models, programs, and services for working with families. Indeed, the Task Force of the Family and Parent Intervention domain can be commended for its diligent and thorough approach to uncovering and dissecting research in this domain. Speaking through the lens of a researcher in this area, the purpose of the present commentary is to highlight some of the findings of the task force, recommend research priorities, and call for the identification of means to increase the utility of the Task Force findings in the future.

\section{WHAT WE KNOW AND NEED TO KNOW}

A major contribution of the work of the Task Force is the identification of several programs that meet criteria to be considered efficacious or promising in addressing school-based concerns in children and adolescents. That is, speaking at a very general level, the research team has uncovered various interventions "that work." Examples include intervention models such as Parent Child Interaction Therapy (Hembree-Kigin \& McNeil, 1995), Incredible Years (Webster-Stratton, Reid \& Hammond, 2001), PARTNERS (Webster-Stratton, 1998), ParentTeacher Action Research teams (McConaughy, Kay, \& Fitzgerald, 1999), family literacy (Morrow \& Young, 1997), home-school notes (Blechman, Taylor, \& Schrader, 1981), Conjoint Behavioral Consultation (Sheridan, Kratochwill, \& Bergan, 1996), parent tutoring (Duvall, Delquadri, Elliot, \& Hall, 1992; Hook \& DuPaul, 1999; Mehran \& White, 1988), Parents Encourage Pupils (Shuck, Ulsh, \& Platt, 1983), Aware Parenting (Bronstein et al., 1998), Multidimensional Family Therapy (Liddle et al., 2001), and Problem-Solving Skills Training with Parent Management Training (Kazdin, Siegel, \& Bass, 1992). We also know that 
there is documented support for models that address various specific needs, such as homework, compliance, literacy, and social skills. Furthermore, programs that bring families and schools together through means such as consultation or structured communication tend to fare better than those that work in isolation.

Despite the identification of some "knowns" related to parent and family interventions, the Task Force has also effectively identified several "unknowns." It is clear from the review that much more research needs to be focused on enhancing the methodological rigor of research in the area of family and parent interventions. In the same vein, attention needs to be focused on family interventions for children from diverse backgrounds, incorporating culturally relevant criteria. Likewise, little is known about the contexts in which research studies were conducted, raising questions that go beyond "what works" to "what effects can be expected using a given intervention in a given setting with a given student or family from a given background exhibiting a given type of concern at a given time in the student's development." Thus, at present we do not know the extent to which we can generalize findings of specific studies to various environments, samples, conditions, individuals, and other important features of intervention contexts. Similarly, much more needs to be known about the elements of the interventions themselves, in terms of their complexity, implementation issues, and operative features.

\section{A CHARGE TO THE FIELD}

The implications of this work are enormous and far-reaching. They include implications for research, practice, and training, and they raise exciting opportunities for the future. Two specific priorities arise if we are to move the field forward in a significant way. First, as has already been alluded to, it is critical that researchers embrace the importance of increased rigor in research related to family interventions, with particular attention to methods for advancing standards for empirical scrutiny. Second, and highly related, is the need to develop mechanisms for understanding how research can inform and be informed by practice in a much more meaningful way. Each of these will be addressed briefly.

\section{Increased Rigor in Research}

Despite the increasing empirical support for the efficacy and social validity of some forms of family interventions, clear and important research challenges remain. In light of increasing demands for accountability and evidence of empirical support for interventions implemented in schools, the demand for increased rigor in our research is upon us. There are still basic questions to be considered, and they must be addressed with careful, systematic, sound research designs. As indicated in the reviews within this series, despite many research studies having been conducted across the several forms of parent and family intervention, few have met the standards for rigorous methodological 
design. Randomized trials have become the "gold standard" in intervention research. Although some controversy remains regarding their exclusionary use, researchers in the human/social/educational sciences (including school psychology researchers) must embrace the highest standards of empirical rigor in whichever approach is appropriate to answer their primary research questions. Unfortunately, with a few exceptions, this has not been the case in the area of parent and family interventions in schools.

The National Association of School Psychologists recently adopted a position statement on Prevention and Intervention Research in the Schools, formally recognizing the importance of well-controlled experimental studies in natural settings such as schools. At the same time, the position statement calls for an expansion of methodologies and the application of a range of valid and rigorous research methods (including randomized control, quasi-experimental, single-participant, mixed method, ethnographic case study, and participatory action research) selected on the basis of specific research questions. Research in the area of family and parent interventions can certainly benefit from a breadth of research approaches applied with the highest levels of sophistication and rigor, framed to address complex questions related to efficacy and beyond.

Researchers must begin investigating the complex nature of family and parent interventions in applied settings. Interactions between participants, interventions, and settings in which they are delivered must be considered. Few, if any, of the family intervention research studies identified herein have identified mediating and moderating variables and their specific relationship to outcomes. Sustainability of family interventions and long-term maintenance of their effects are areas that are virtually untapped in the existing research base. Similarly, effects of interventions on relationships between children and families, children and teachers, and parents and teachers are important issues in relation to family interventions in schools. New and sophisticated research designs will be required to address several of these agendas. This includes those that recognize the unique contextual features of practice settings (e.g., the nested nature of students within classrooms within schools) and model change over time.

\section{The Research-Practice Link}

It is critical to understand the research-practice link if the work of this Task Force is to have relevance in the future of school psychology and in the lives of children and families. Beyond questions related to efficacy and effectiveness, practice issues include feasibility, acceptability, social validity, fidelity, and sustainability.

The utility of this work will be realized only if researchers and practitioners work in concert with each other. As a research community, school psychology must engage in research that allows us to understand contextual features of practice. As a practice community, school psychology must engage in efforts to alter structures (e.g., roles, organizations) and insist upon the use and continual evolution and evaluation of evidence-based practices. We need to understand 
how to take research findings "to scale," and this can happen only under conditions where both research and practice demands are realized and respected. We need to understand what is involved in implementing or institutionalizing the programs in natural community practice contexts. Likewise, we need strategic efforts to infuse evidence-based practices into the fabric of the field.

Translating the research base to practice will take a concerted effort that involves infrastructure changes and reallocation of efforts - changes in the supports and mechanisms of what practitioners do, how they are supported in doing it, and how they will be accountable. Relatedly, difficult decisions will need to be made at the training/institution level. We can no longer continue to train students in models or programs that fail to demonstrate efficacy, simply because of tradition or mandates that do not stand up to empirical scrutiny.

Implications for the future of school psychology are great. We have an unprecedented opportunity to forge great inroads related to family and parent interventions in schools. Based on the findings we can be more confident than ever of the importance of family-school partnerships on behalf of children's learning. How will the field proceed in the future?

\section{WHAT DOES IT MEAN FOR THE FUTURE?}

It is the hope of this author that the significance of the work of this Task Force does not go unnoticed. The work represented in this special series sets the stage for what should become a major priority for the field. It should establish an important agenda for the future of school psychology. We can no longer continue working in ways that fail to consider the significant systems that influence children's lives - most notably, the family and school systems in interaction with each other. This goal can be accomplished most readily if the efforts of the Task Force are linked directly and intentionally with the "Futures" work of the major stakeholders and constituencies within the field.

At the Future of School Psychology Multi-site Conference in 2002, a number of researchers, trainers, practitioners, and graduate students in school psychology came together and focused diligently and cooperatively on one major task: charting the course for our future. The Task Force on Home-School Partnerships was created at the conference and has continued work (and now in partnership with state-level efforts) to establish goals, action steps, and strategies for infusing this critical domain into the field, front and center. The goals articulated by the task force were threefold, and they encompass the identification of evidence-based models, incorporation of research-based findings into the service delivery structure of the field, and the inclusion of home-school partnership efforts into training programs. The specific goals and action steps of the Futures Task Force are stated in Table 1. The thorough and ambitious work by the Task Force of the Family and Parent Intervention domain establishes important groundwork for real and meaningful change to occur. Through their work, Goal A of the Futures Task Force is well on its way, and important progress is being made related to Goals $\mathrm{B}$ and $\mathrm{C}$. 
Table 1. Goals and Action Steps of the Futures Task Force on Home-School Partnerships

Goal A: Identify evidence-based models of effective family-school partnerships. Actions/Activities:

- Identify outcome-based literature that describes processes and procedures related to family-school partnership models.

- Identify models of "best practice" related to family-school partnerships for use in training programs and practice settings.

Goal B: Ensure that school psychologists engage in activities to change the culture of schooling to ensure that families are integral partners in the educational process of children.

Actions/Activities:

- Develop materials for inservice training.

- Develop a mechanism for dissemination at the state level.

- Explore the possibility of linking to continuing education opportunities.

- Connect meaningful family-school partnership priorities with current legislation and policy.

Goal C: Change pre-service education and training of school psychology candidates to infuse a focus on families as integral partners in the educational process.

Actions/Activities:

- Identify effective process variables that assist in the establishment of effective homeschool partnerships.

- Identify effective process variables that assist in the establishment of effective homeschool partnerships with diverse populations.

- Develop materials for presentations at trainers' meetings.

- Develop training modules for use in graduate programs.

For the field of school psychology to experience a meaningful shift, intentional efforts are required related to what was initiated at the Futures Conference. The interface of continued research initiatives, practice efforts, and training is critical. Scholarly and practice communities (e.g., university and professional organizations such as Division 16 of the American Psychological Association and the National Association of School Psychologists) must work in tandem. Empirical efforts are needed to translate research into practice settings and understand contextualized implementation issues if we are to expect to impact service delivery in a meaningful way. Similarly, individuals working in practice contexts must embrace a scientific approach and help specify priorities, structures, and elements of effective implementation in "real life" applied settings. By working in intentional and collaborative ways, there are now unparalleled opportunities to ensure that effective models for working with families become embedded in the heart of school psychology. 


\section{References}

Blechman, E. A., Taylor, C. J., \& Schrader, S. M. (1981). Family problem solving versus home notes and early intervention with high-risk children. Journal of Consulting and Clinical Psychology, 49, 919-926.

Bronstein, P., Duncan, P., Clauson, J., Abrams, C. L., Yannett, N., Ginsburg, G., \& Milne, M. (1998). Preventing middle school adjustment problems for children from lower-income families: A program for aware parenting. Journal of Applied Developmental Psychology, 19, 129-152.

Duvall, S. F., Delquadri, J. C., Elliott, M., \& Hall, R. V. (1992). Parent tutoring procedures: Experimental analysis and validation of generalization in oral reading across passages, settings, and time. Journal of Behavior Education, 2, 281-303.

Hembree-Kigin, T. L., \& McNeil, C. B. (1995). Parent Child Interaction Therapy. New York: Plenum Press.

Hook, C. L., \& DuPaul, G. J. (1999). Parent tutoring with attention-deficit/hyperactivity disorder: Effects on reading performance at home and school. School Psychology Review, 28, 60-75.

Kazdin, A. E., Siegel, T. C., \& Bass, D. (1992). Cognitive problem-solving skills training and parent management training in the treatment of antisocial behavior in children. Journal of Consulting and Clinical Psychology, 60, 733-747.

Liddle, H. A., Dakof, G. A., Parker, K., Diamond, G. S., Barret, K., \& Tejada, M. (2001). Multidimensional family therapy for adolescent drug abuse: Results of a randomized clinical trial. American Journal of Drug and Alcohol Abuse, 27, 651-688.

McConaughy, S. H., Kay, P. J., \& Fitzgerald, M. (1999). The achieving, behaving, caring project for preventing ED: Two-year outcomes. Journal of Emotional and Behavioral Disorders, 7, 224-239.

Mehran, M., \& White, K. R. (1988). Parent tutoring as a supplemental compensatory education for first-grade children. Remedial and Special Education, 9(3), 35-41.

Morrow, L. M., \& Young, J. (1997). A family literacy program connecting school and home: Effects on attitude, motivation, and literacy achievement. Journal of Educational Psychology, 89, 736-742.

Sheridan, S. M., Kratochwill, T. R., \& Bergan, J. R. (1996). Conjoint behavioral consultation: A procedural manual. New York: Plenum.

Shuck, A., Ulsh, F., \& Platt, J. S. (1983). Parents encourage pupils (PEP): An innercity parent involvement reading project. The Reading Teacher, 524-528.

Webster-Stratton, C. (1998). Preventing conduct problems in Head Start children: Strengthening parenting competencies. Journal of Consulting and Clinical Psychology, 66, 715-730.

Webster-Stratton, C., Reid, M. J., \& Hammond, M. (2001). Preventing conduct problems, promoting social competence: A parent and teacher training partnership in Head Start. Journal of Clinical Child Psychology, 30, 283-302.

The action editor for the School Psychology Quarterly edition of this article was Cindy Carlson. 
Susan Sheridan, Ph.D., is a Willa Cather Professor in the College of Education and Human Sciences at the University of Nebraska-Lincoln. She is the Director of the Nebraska Center for Research on Children, Youth, Families and Schools and Editor of School Psychology Review. She conducts research and has authored several books, chapters and journal articles on family-school partnerships, parent engagement and involvement in learning, and social skills interventions. She was the recipient of the 1993 Lightner Witmer Award, bestowed by Division 16 (School Psychology) of the American Psychological Association for early career accomplishments. The School Psychology Program at the University of Nebraska-Lincoln is accredited by the APA. 